\title{
SHORTER EssaY
}

\section{The Division of Labor Under Homogeneity A Critique of Mises and Rothbard}

\author{
By Walter Block, Per Henrik Hansen, and Peter G. Klein*
}

\begin{abstract}
Even the most passionate defenders of free trade, such as Mises and Rothbard, claim that trade cannot occur under conditions of strict homogeneity of land, labor, and capital. We show that specialization, trade, and the division of labor can emerge even when resources are initially homogenous, due to "natural heterogeneity," economies of scale, and learning.
\end{abstract}

Perhaps no proposition in economic theory is better established than the idea of gains from trade. The insight that voluntary exchange is mutually beneficial was articulated as early as the 13th century by Richard of Middleton (de Roover 1963: 338), reaching its full expression in Ricardo's ([1817] 1951) law of association, or the principle of comparative advantage. These insights are not always well understood, of course. The mercantilist view of trade suffers from what Mises (1966: 664) calls the "Montaigne fallacy," the belief that trade benefits one party at the expense of the other. ${ }^{1}$

\footnotetext{
*Walter Block is Harold E. Wirth Eminent Scholar in Economics at Loyola University, New Orleans, 6363 St. Charles Avenue, New Orleans, LA 70118; e-mail: wblock@ loyno.edu. He is author of a dozen books and over 200 scholarly articles on economics, law, and political philosophy. Per Henrik Hansen is a Ph.D. Fellow in the Department of Economics, Copenhagen Business School, 2000 Frederiksberg, Denmark; e-mail: phh.eco@cbs.dk. He is a former Mises Institute Fellow and a specialist in monetary economics. Peter G. Klein is Assistant Professor in the Division of Applied Social Sciences and Associate Director of the Contracting and Organizations Research Institute, 135 Mumford Hall, University of Missouri, Columbia, MO 65211; e-mail: pklein@ missouri.edu. His research focuses on entrepreneurship, industrial economics, and the economics of organizations and institutions. The authors are grateful to Laurence Moss (the editor) and two referees for insightful comments on a previous draft. The usual disclaimer applies.
}

American Journal of Economics and Sociology, Vol. 66, No. 2 (April, 2007).

(c) 2007 American Journal of Economics and Sociology, Inc. 
This article attempts to clarify an assumption underlying the principle of gains from trade. Most expositors begin by stating that trade is mutually beneficial only if factors of production vary in their attributes. Resource heterogeneity is thus a prerequisite for the gains from trade. Mises (1966: 157), for example, states that "if the earth's surface were such that the physical conditions of production were the same at every point and if one man were... equal to all other men ... [the] division of labor would not offer any advantages for acting man." Rothbard (1962: 82) adds: "It is a fact that, superimposed on the basic unity of species and objects in nature, there is a great diversity. Particularly is there variety in the ... factors that would give rise to specialization: in the locations and types of natural resources and in the ability, skills, and tastes of human beings. . . It is clear that conditions for exchange, and therefore increased productivity for the participants, will occur where each party has a superiority in productivity in regard to one of the goods exchanged - a superiority that may be due either to better nature given factors or to the ability of the producer." Further, Rothbard (1982: 35) maintains: "If all people were equally skilled and equally interested in all matters, and if all areas of land were homogeneous with all others, there would be no room for exchanges."

We argue here that specialization, trade, and the division of labor can take place even if all human and nonhuman resources were exactly alike. We do not disagree with Mises and Rothbard that resource heterogeneity is sufficient to create gains from trade. ${ }^{2}$ However, we deny that resource heterogeneity is a necessary condition in order for gains from trade to be possible. In other words, a division of labor can exist even under resource homogeneity.

Suppose that human beings were all completely interchangeable; they had the same skills, capacities, initiative, intelligence, tastes, and so on as each other. Posit, further, that all land, too, was completely homogeneous: equally fertile, equally watered, equally ground covered, with equal access to whatever amenity anyone cared to name. In addition, we assume that all people and resources are located randomly throughout the world; that is, that there is no grouping of either persons or raw materials based upon any unique or even different characteristics; there cannot be, in any case, because of 
our other homogeneity assumptions. Under these admittedly unrealistic conditions, would trade be possible, or would all the people depicted in this scenario be forced to rely solely upon self-sufficient production?

Rothbard states in this regard:

In describing the conditions that must obtain for interpersonal exchange to take place (such as reverse valuations), we implicitly assumed that it must be two different goods that are being exchanged. If Crusoe at his end of the island produced only berries, and Jackson at his end produced only the same kind of berries, then no basis for exchange between them would occur. If Jackson produced two hundred berries and Crusoe one hundred fifty, it would be nonsensical to assume that any exchange of berries would be made between them. (1992: 80)

We agree with Rothbard that at least two goods are needed, but maintain that resource heterogeneity does not imply a one-good model. Suppose, for example, that there are two people, Jackson and Crusoe, each with equal abilities, and that there are two goods, fish and berries, such that each of these people can, at the outset, produce an identical number of each product. Let us assume for illustration purposes that both can produce 200 berries, and 20 fish, in a two-day period. We posit a very simple world with no capital goods. Berries are picked by hand, and fish are caught by grabbing them, as is now done by bears. We concede that under these conditions no trade will occur, and certainly productivity could not thereby be enhanced. ${ }^{3}$

However, under reasonably weak assumptions, conditions for mutually beneficial exchange can emerge. First, individuals can never be 100 percent identical, simply because they cannot occupy the same physical space. Even if they are completely identical in every other regard, it is possible (though not necessary) that they have different access to complementary resources. Imagine that the berry bushes are adjacent to the beach. If Crusoe is standing a tiny bit closer to the berry bushes, and Jackson a tiny bit closer to the water, then there are gains from trade by Crusoe specializing in berries and Jackson specializing in fish. That is, the two laborers are identical in each aspect besides location, but they have different costs of production. The one closet to berries has a lower cost of berry production than the one closest to fish, and so on. 
More generally, location is a unique attribute, an ontological fact about the real world. One of the characteristics of any resource is its location. That means that, strictly speaking, there is and can be no such thing as completely homogeneous resources. George's (2003) great insight was that no two plots of land are really identical because land always exists at a particular location. Location is nonreplicable, and this gives rise to certain specific patterns of income distribution. ${ }^{4}$

Second, from a subjectivist, Austrian perspective, the value of a resource as used in production is driven not by its objective, physical characteristics, but by its place in the structure of production, as conceived by entrepreneurs. ${ }^{5}$ Even resources that are physically identical (subject to the caveat about location just discussed) are not "identical" in the sense relevant to economic analysis. We can imagine that Crusoe's and Jackson's island is also inhabited by entrepreneurs who organize fish and berry production, hiring Crusoe and Jackson as employees. The "true" value of Crusoe's and Jackson's labor in either production process is unknown. One entrepreneur estimates Crusoe's marginal productivity as sufficient to make berry production profitable but not fish production, so she hires Crusoe, placing him into the economy's production process for berries. Another entrepreneur then hires Jackson to produce fish. The labor services of Crusoe and Jackson are now heterogeneous resources, meaning that they are assigned different positions in the economy's capital structure, even though Cruse and Jackson are identical human beings.

Even if we ignored these points about what we might call "natural" or "ontological" heterogeneity, there would be additional sources of potential gains. In both cases, individuals start out identical, but become differentiated by their actions.

Let us develop this point further. Assume now that Crusoe and Jackson are equidistant from berries and fish. Is it still possible for each to "gravitate" to a different resource and, having done so, come to specialize in that one and thereby raise productivity? Such a state of affairs might be considered an accident, ${ }^{6}$ but there is no reason to rule it out. Not every Crusoe and Jackson pair might arrange matters in such a way, but it is difficult to see why none of these hypothetical pairs could do so. If one or both production processes are characterized by increasing returns to scale, then such specialization-even if 
random-results in net gains. It does not seem unrealistic to expect that over time Jackson and Crusoe-being rational human beingswill realize from their experience in autarchy that the more they produce the better they get at it. They will eventually also realize that the larger the scale of production the better are the opportunities for the use of tools and eventually mechanization of production. When one of them, let us say Crusoe, has so realized, we can imagine that he approaches Jackson and explains this to him. They then agree each to specialize in production of a different good in order to be able to share a larger amount of both at the end of the period.

How would they agree on who would specialize in what? One possibility is that they have different preferences for the attributes of the work environment they consume while working. Producing fish and "fishing" are not separable; one may enjoy fishing while the other enjoys tending berry plants. However, they could also draw lots or simply agree to change production lines every other period. ${ }^{7}$ The point is that having realized the prospect of a potential welfare gain, Jackson and Crusoe will be very resourceful. Mises seems to agree with this, as he writes:

If and as far as labor under the division of labor is more productive than isolated labor, and if and as far as man is able to realize this fact, human action itself tends toward cooperation and association; man becomes a social being not in sacrificing his own concerns for the sake of a mythical Moloch, society, but in aiming at an improvement in his own welfare. (1966: 160)

There is another and perhaps more likely way that specialization could come about. Crusoe-having realized the potential gains of specialization-could start, unilaterally, to change the proportions of his own production of the two goods. Assuming that there are increasing returns to scale, this action by Crusoe would imply that the relationship between the two goods in terms of opportunity costs will be different when seen from the perspective of Crusoe relative to that of Jackson. The different marginal transformation rates between the two goods for Crusoe and Jackson would then provide the basis for beneficial marginal trade between them. This initial change by Crusoe will be reinforced by their new experience. 
Even in the absence of scale economies, if there are "learning effects" (i.e., average cost is a decreasing function of accumulated output), then one or both workers can lower his average costs over time. ${ }^{9}$ Assume that if the two of them specialized, it matters not one whit in which of these two goods, that the productivity of each would be improved. For example, if Jackson concentrated on picking berries alone, and Crusoe focused on fishing only, let us suppose that the former could pick 500 berries in two days, while the latter could catch 50 fish in that amount of time. Together, they could each potentially ${ }^{10}$ have more of both goods than if each worked in isolation, without trade. We do not need heterogeneity to reach this conclusion, only the supposition that specialization enhances productivity. Learning is particularly important in this geographical or "locational" analysis. This is in sharp contradistinction to the typical textbook models of equilibrium economics, which either ignore these crucial elements of economics or give them short shrift.

In short, even under complete homogeneity, specialization, division of labor, and trade can arise. A sufficient condition for such trade to arise is simply that learning and practice bring improvement. This is significant in that it demonstrates the robustness of free trade: it can take place even in the face of homogeneity. Even such notable defenders of free trade as Mises and Rothbard did not make this point explicit in their analysis. ${ }^{11}$

\section{Notes}

1. Even today, the Montaigne fallacy plagues discussions of outsourcing, "off-shoring," and increased international capital mobility. Irwin (2005) summarizes recent controversies over trade theory and policy.

2. In making this claim, we are implicitly assuming a whole host of other factors to be in play: sufficient knowledge, a legal system supportive of trade or at least not too disruptive of it, and so forth.

3. If tastes were different, trade might well occur. Let us suppose that Jackson was a vegetarian, a herbivore, and Crusoe a carnivore. Under these conditions, Crusoe would give up his berries for the fish of Jackson; thus, specialization, the division of labor, and greater productivity would ensue. But we are assuming complete homogeneity, including tastes, so this result is ruled out.

4. The authors are grateful to Laurence Moss for this point. For more on George, see Moss (2001, 2005). 
5. More precisely, it is not physical assets themselves, but their attributes - the characteristics, functions, or possible uses of assets, as perceived by entrepreneurs-that are valued and priced on factor markets. On this point, see Foss, Foss, Klein, and Klein (2007).

6. We abstract from all issues related to indifference; for example, if they were both equidistant from berries and fish, would they just stand there like Buridan's Ass, and starve to death? For a debate on indifference, see Nozick (1977), Block (1980, 1999, 2003), Caplan (1999, 2000, 2001), Hülsmann (1999), and Hoppe (2005).

7. If they did this, some of the benefits from practice would be lost, but it still might well be a better outcome than no trade at all.

8. It cannot be denied that heterogeneity is of considerable helpfulness in getting the division of labor underway. And that, really, is an understatement. We readily concede that without heterogeneity, the amount of specialization would be very small. Perhaps it might not even exist at all. But it might. There is no theoretical reason why it could not, Mises and Rothbard to the contrary notwithstanding.

9. Both Mises and Rothbard accept the idea of learning by doing. Mises (1966: 164) writes: "Exercise and practice of specific tasks adjust individuals better to the requirements of their performance; men develop some of their inborn faculties and stunt the development of others. Vocational types emerge, people become specialists." Adds Rothbard (1962: 82): "full-time specialization in a line of production is likely to improve each person's productivity in that line and intensify the relative superiority of each."

10. Depending upon the terms of trade that were agreed upon; at the very least, neither would have less.

11. One could respond that neither Mises nor Rothbard intended to generalize their statements quoted above beyond an environment of constant returns and no learning effects. They left no indication that they meant to include such qualifiers, however. We thank a referee for raising this point.

\section{References}

Block, Walter. (1980). "On Robert Nozick's 'On Austrian Methodology'." Inquiry 23(4): 397-444.

—. (1999). "Austrian Theorizing, Recalling the Foundations: Reply to Caplan." Quarterly Journal of Austrian Economics 2(4): 21-39.

—. (2003). "Realism: Austrian vs. Neoclassical Economics: Reply to Caplan." Quarterly Journal of Austrian Economics 6(3): 63-76.

Caplan, Bryan. (1999). "The Austrian Search for Realistic Foundations." Southern Economic Journal 65(4): 823-838.

. (2000). "Probability, Common Sense, and Realism: A Reply to Hülsmann and Block." Quarterly Journal of Austrian Economics 4(2): 69-86. 
- (2001). "Probability, Common Sense, and Realism: A Reply to Hülsmann and Block." Quarterly Journal of Austrian Economics 2(4): 69-86.

Foss, Kirsten, Nicolai J. Foss, Peter G. Klein, and Sandra K. Klein. (2007). "The Entrepreneurial Organization of Heterogeneous Capital." Journal of Management Studies, forthcoming.

George, Henry. ([1879] 2003). Progress and Poverty. New York: Robert Schalkenbach Foundation.

Hoppe, Hans Hermann. (2005). "A Note on Preference and Indifference in Economic Analysis." Quarterly Journal of Austrian Economics 8(4): 87-91.

Hülsmann, Jörg Guido. (1999). "Economic Science and Neoclassicism." Quarterly Journal of Austrian Economics 2(4): 1-20.

Irwin, Douglas A. (2005). Free Trade Under Fire, 2nd ed. Princeton, NJ: Princeton University Press.

Mises, Ludwig von. (1966). Human Action, 3rd ed. Chicago: Regnery.

Moss, Laurence S. (2001). "Why the Preaching Must Never Stop: Henry George's and Paul Krugman's Respective Contributions to the Free Trade Debate." In The Path to Justice: Following in the Footsteps of Henry George. Supplement to the American Journal of Economics and Sociology 60(5): 135-161.

—. (2005). "The Henry George Theorem: Turning Henry George on His Head." In The Economics of Henry George. Ed. John Laurent. Cheltenham, UK: Elgar Publishers.

Nozick, Robert. (1977). "On Austrian Methodology.” Synthese 36: 353-392.

Ricardo, David. ([1817] 1951). "The Principles of Political Economy and Taxation." In The Works and Correspondence of David Ricardo. Eds. Piero Sraffa and M.H. Dobb. Cambridge: Cambridge University Press.

de Roover, Raymond. ([1963] 1974). "The Scholastic Attitude Toward Trade and Entrepreneurship." In Business, Banking, and Economic Thought in Late Medieval and Early Modern Europe: Selected Studies of Raymond de Roover. Chicago: University of Chicago Press.

Rothbard, Murray N. ([1962] 1993). Man, Economy and State. Auburn, AL: Mises Institute.

. ([1982] 1998). The Ethics of Liberty. Atlantic Highlands, NJ: Humanities Press. 